\title{
FIRST RECORDS OF POLYDRUSUS (CONOCETUS) CRINIPES GERMANN, 2018 FROM CROATIA AND ALBANIA (COLEOPTERA, CURCULIONIDAE)
}

\author{
Christoph Germann ${ }^{1 *}$ \& Tamas Nemes ${ }^{2}$ \\ ${ }^{1}$ Curator Biosciences, Natural History Museum Basel, Augustinergasse 2, CH-4001 Basel, Switzerland \\ (e-mail: germann.christoph@gmail.com) \\ 2Jávor u. 5/B, 1145 Budapest, Hungary (e-mail: tamas@liveinsectbox.net)
}

\begin{abstract}
Germann, Ch. \& Nemes, T.: First records of Polydrusus (Conocetus) crinipes Germann, 2018 from Croatia and Albania (Coleoptera, Curculionidae). Nat. Croat. Vol. 28, No. 1., 177-180, Zagreb, 2019.

The first records of Polydrusus (Conocetus) crinipes Germann, 2018 from southern Croatia and Albania considerably enlarge the species' distribution towards the Northwest. The species has been previously confined to Greece and Bulgaria. The habitat at Baćinska lakes, where the species was discovered in Croatia, fits well with its ecological preferences.
\end{abstract}

Key words: Croatia, Albania, faunistics, Polydrusus crinipes, new record

Germann, Ch. \& Nemes, T.: Prvi nalaz Polydrusus (Conocetus) crinipes Germann, 2018 za Hrvatsku i Albaniju (Coleoptera, Curculionidae). Nat. Croat. Vol. 28, No. 1., 177-180, Zagreb, 2019.

Prvi nalazi vrste Polydrusus (Conocetus) crinipes Germann 2018 u južnoj Hrvatskoj i Albaniji značajno povećava rasprostranjenje vrste prema sjeveru. Vrsta je dosad bila ograničena na područje Grčke i Bugarske. Stanište na Baćinskim jezerima, gdje je vrsta pronađena u Hrvatskoj, u skladu je s njenim ekološkim sklonostima.

Ključne riječi: Hrvatska, Albanija, faunistika, Polydrusus crinipes, novi nalaz.

\section{INTRODUCTION}

Within the diverse superfamily Curculionoidea, the genus Polydrusus Germar, 1817 at present comprises 40 species in Croatia (Alonso-Zarazaga et al., 2017). Just recently the subgenus Conocetus Desbrochers des Loges, 1875 was reviewed, an identification key for all eleven valid species was given, and the distribution of all species was investigated in detail (Germann, 2018). As Polydrusus (Denticonocetus) kahri Kirsch, 1865 - present in Croatia - does not belong to the subgenus anymore, the record of Polydrusus crinipes is the first one of the entire subgenus Conocetus for Croatia. From Albania, only Polydrusus (Conocetus) marcidus Kiesenwetter, 1864 was, quite recently, recorded from that subgenus (Germann, 2018), and ApFelbecK (1922) mentioned Polydrusus bardus Gyllenhal, 1834 (under its synonymous name gracilicornis Kiesenwetter, 1864) from Oroshi, Albania. However, it is unclear if $P$. bardus or P. crinipes was meant. The newly described Polydrusus crinipes was in part a misinterpretation of Polydrusus bardus, or one of its many synonyms. Only 
the examination of the holotype, conserved in the Swedish Museum of Natural History, Stockholm, allowed this misidentification to be unravelled. Despite this confusion, neither Polydrusus bardus, in the past sense, nor Polydrusus crinipes was ever recorded in Croatia. Hence the present discovery of $P$. crinipes in southern Croatia is indeed a surprise. The circumstances of the record are given and discussed, the specimen is depicted and an overview of its present distribution is provided.

\section{RESULTS AND DISCUSSION}

A single female specimen (Fig. 1) just freshly emerged, as the mandibular scar is still visible on the left mandible (this prolongation easily breaks off just hours after hatching) was found by hand and photographed by the co-author at Baćinska jezera in the South of Croatia, coordinates $43^{\circ} 4^{\prime} 33^{\prime \prime} \mathrm{N}, 17^{\circ} 25^{\prime} 18^{\prime \prime} \mathrm{E}$ on June 3 in 2017. The specimen was not collected, but a photo was taken for

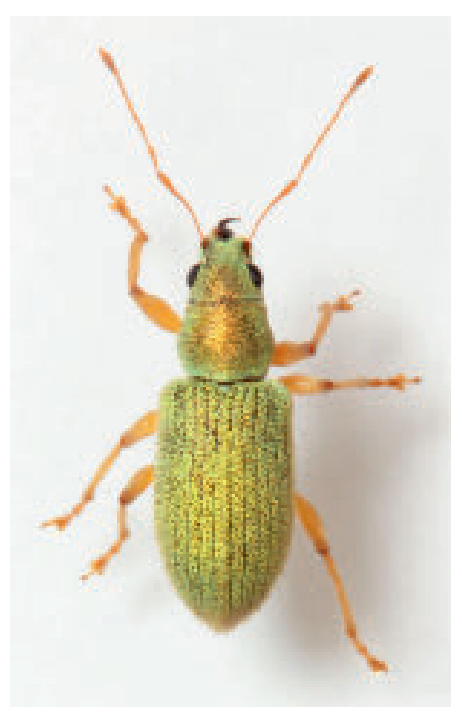

Fig. 1. Polydrusus (Conocetus) crinipes, female, Croatia: Baćinska jezera (scale $1 \mathrm{~mm}$; photo: T. Nemes). determination and as proof of its presence. The habitat can be characterized as an ecotone between poplar woods and lakeside reeds. The species has in general typically been collected mainly near streams, lakes or lagoons, and shows a certain affinity for deciduous trees (GERMANN, 2018). Hence the present record at Bacinska Lake fits well with these supposed ecological preferences. The other specimen from Albania is a male from Tepelenë, $2 \mathrm{~km}$ NW Memaliaj, N $40^{\circ} 21.867^{\prime}, \mathrm{E} 19^{\circ} 57.716^{\prime}, 140 \mathrm{~m}$ a. s. 1. collected on May 19 in 2018 by Hans Mühle (Natural History Museum Basel collection). The specimen was similarly collected along the floodplains of a river, the Viosa, which again fits with the species' preferences.

To date Polydrusus crinipes was only known from the localities of the type material, hence from southern Bulgaria and Greece (Fig. 2). The present record shows, that $P$. crinipes is certainly wider distributed at least along the Dalmatian coast and reaches Croatia in the South. In these countries several older researchers, e.g. Victor Apfelbeck 1859-1934, working extensively on Polydrusini (APFelbeck, 1922), made intensive collection efforts. Apfelbeck (1922) listed five species under the subgenus Conocetus in his article, where the mentioned "bardus Gyllh." with a single locality "Varna" in Bulgaria might have referred to crinipes in the present sense.

One reason why despite these collections, this rather big $(4.5 \mathrm{~mm})$ and colourful species has not been recorded - especially along the coast from Albania and Montenegro to Bosnia and Herzegovina and more northerly along the Croatian 


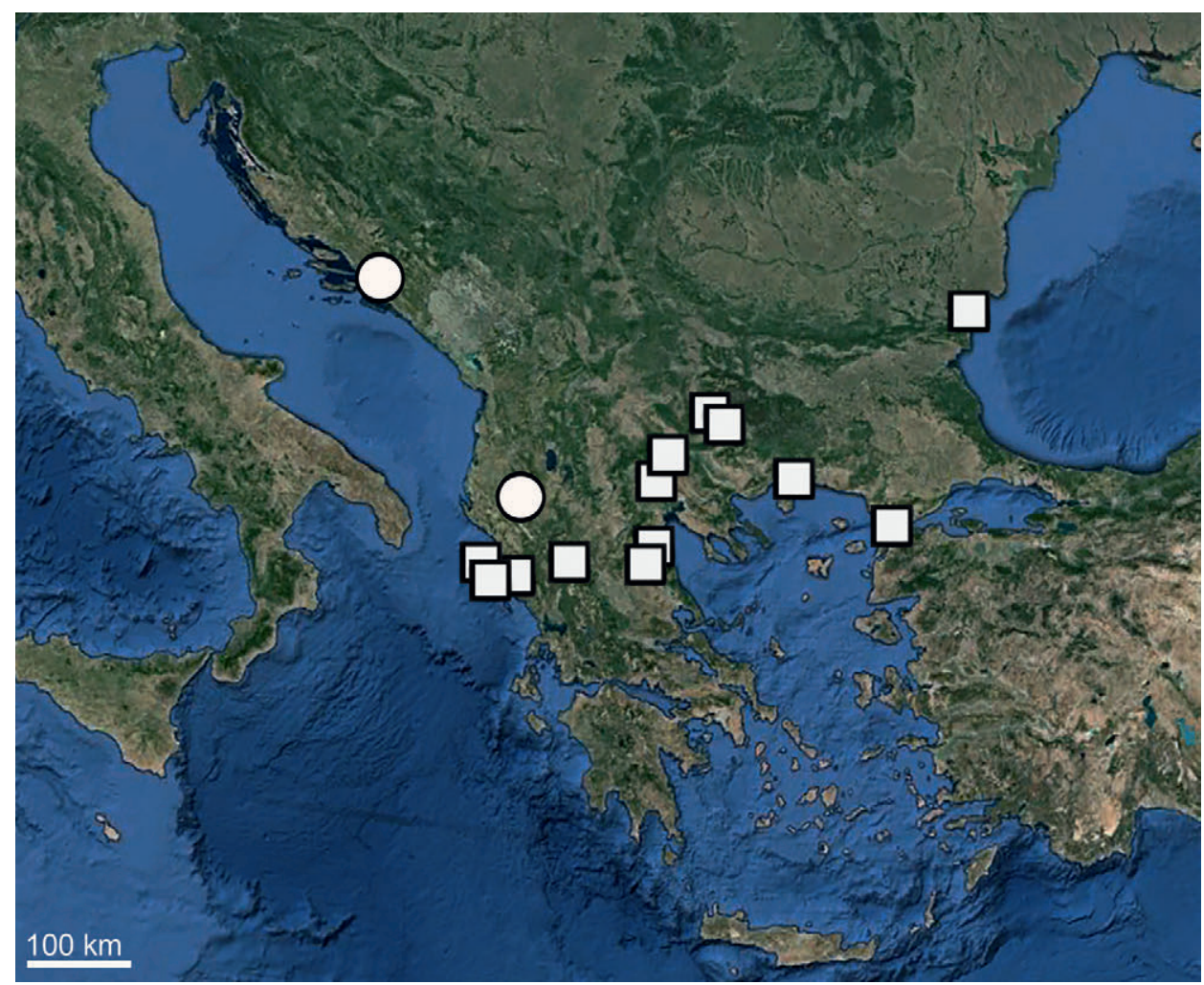

Fig. 2. Records of Polydrusus (Conocetus) crinipes taken from literature (squares - GermanN, 2018; Apfelbeck, 1922), including the present records from southern Croatia and Albania (circles).

coast - might be the generally short appearance time of many Polydrusus which is often limited to a single peak of several weeks from spring till early summer, depending on the altitude involved. This makes it more difficult to detect them. An expansion of the inhabited area is another possible explanation for the present records, both dating back to very recent findings, but more data is needed to prove this hypothesis.

One goal of our article is to encourage other entomologists to keep an eye out for possible occurrences of Polydrusus crinipes in the Balkans. As shown here, good photos can help in identifying and thus recording the species.

\section{ACKNOWLEDGMENTS}

We thank Hans Mühle (Nußdorf am Inn, Germany) for the donation of his collected weevils, and Dr. Maja Čačija (University of Zagreb, Faculty of Agriculture, Department for Agricultural Zoology) for the translation of the abstract into Croatian. Thanks to the reviewers for their helpful comments and criticism. 


\section{REFERENCES}

Alonso-Zarazaga, M.A., Barrios, H., Borovec, R., Bouchard, P., Calda ra, R., Colonnelli, E., Gültekin, L., Hlaváč, P., Korotyaev, B., Lyal, C.H.C., Machado, A., Meregalli, M., Pierotti, H., Ren, L., Sánchez-Ruiz, M., Sforzi, A.,Silfverberg, H., Skuhrovec, J., Trýzna, M., Velázquez de Castro, A.J. \& Yunakov, N.N., 2017: Cooperative Catalogue of Palaearctic Coleoptera Curculionoidea. Monografías electrónicas de la Sociedad Entomológica Aragonesa 8, 1-729.

Apfelbeck, V., 1922: Fauna insectorum balcanica. VIII. Zur Kenntnis der balkanischen Curculioniden (Col.). Revision der Gattungen Polydrosus Germ, und Sciaphobus Dan. Glasnik Zemaljskog Muzeja u Bosni i Hercegovini 33-34, 49-72.

Germann, C., 2018: A review of Conocetus Desbrochers des Loges, 1875, subgenus of Polydrusus Germar, 1817 (Coleoptera, Curculionidae, Entiminae). European Journal of Taxonomy 392, 1-39. 